\title{
Teaching of pressure injury prevention and treatment using simulation
}

\author{
Ensino de prevenção e tratamento de lesão por pressão utilizando simulação \\ La enseñanza de la prevención y el tratamiento de la lesión por presión usando simulación
}

\author{
Alessandra Mazzo ${ }^{1}$ \\ Fernanda Berchelli Girão Miranda ${ }^{1}$ \\ Mateus Henrique Gonçalves Meska ${ }^{1}$ \\ Anaísa Bianchini ${ }^{1}$ \\ Rodrigo Magri Bernardes ${ }^{1}$ \\ Gérson Alves Pereira Junior ${ }^{1}$
}

1. Universidade de São Paulo.

Ribeirão Preto, SP, Brazil.

\section{Abstract}

Objective: To describe the construction of a high-fidelity clinical scenario simulation of "Pressure injury patient nursing care". Method: Report the experience of constructing a high-fidelity clinical scenario simulation based on the literature and on Bloom's taxonomy. Learning objectives, prior study material, fidelity, clinical case, necessary resources, problem solving, face and content validity, debriefing and evaluation were considered. Results: The scenario included cognitive, psychomotor and affective aspects; role-playing and the moulage technique were used, and it was positively evaluated by the students. Conclusion: The construction of planned, structured and validated simulated clinical scenarios brings learners closer to the clinical practice, allowing the development of the skills required for the prevention and treatment of pressure injuries. Implications for practice: Well-designed simulated clinical settings simulate nursing care training with fidelity to patients with pressure injury.

Keywords: Simulation; Pressure Ulcer; Nursing; Nursing Education; Methods.

\section{Resumo}

Objetivo: Descrever a construção de cenário clínico simulado de alta fidelidade "Assistência de enfermagem ao paciente com lesão por pressão". Método: Relato de experiência de construção de cenário clinico simulado de alta fidelidade, com base na literatura e Taxonomia de Bloom. Foram considerados objetivos de aprendizagem, material de estudo prévio, fidelidade, caso clínico, recursos necessários, resolução de problemas, validação de aparência e conteúdo, debriefing, avaliação. Resultados: o cenário incluiu os aspectos cognitivos, psicomotores e afetivos e utilizado role player e a técnica de moulage. Foi avaliado de forma positiva pelos estudantes. Conclusão: A construção de cenários clínicos simulados planejados, estruturados e validados, aproxima o aprendiz da prática clínica possibilitando o desenvolvimento de competências necessárias para a prevenção e tratamento de lesão por pressão. Implicações para a prática: em cenários clínicos simulados bem delineados aproximam com fidelidade o treino da assistência de enfermagem ao paciente com lesão por pressão.

Palavras-chave: Simulação; Úlcera por pressão; Enfermagem; Educação em enfermagem; Métodos.

\section{Resumen}

Objetivo: Describir la construcción de escenario clínico simulado de alta fidelidad destinado a la enseñanza aprendizaje de la asistencia de enfermería al paciente con lesión por presión. Método: Relato de experiencia de construcción de escenario clinico simulado de alta fidelidad, con base en la literatura y Taxonomía de Bloom. Fueron considerados objetivos de aprendizaje, materia de estudio previo, fidelidad, caso clínico, recursos necesarios, resolución de problemas, validación de apariencia y contenido, debriefing, evaluación. Resultados: El escenario incluyó los aspectos cognitivos, psicomotores y afetivos y utilizado role player y la técnica de moulage. Fue evaluado de forma positiva por los estudiantes. Conclusión: La construcción de escenarios clínicos simulados planificados, estructurados y validados, aproxima al aprendiz con veracidad de la práctica clínica y posibilita el desarrollo de competencias necesarias para la prevención y tratamiento de lesión por presión. Implicaciones para la práctica: Tales recursos auxilian el proceso de enseñanza aprendizaje y la actualización de los profesionales en prevención y tratamiento de lesiones, lo que contribuye positivamente al desarrollo del aprendiz, seguridad y calidad de la asistencia de los pacientes.

Palabras clave: Simulación; Úlcera por Presión; Enfermería; Educación en Enfermería; Métodos.
Corresponding author:

Mateus Henrique Gonçalves Meska.

E-mail: mateus.meska@usp.br

Submitted on $06 / 28 / 2017$.

Accepted on 09/23/2017.

DOI: 10.1590/2177-9465-EAN-2017-0182 


\section{INTRODUCTION}

The profile of an appropriate and valued health professional in the labor market is changing. Thus, training with the necessary knowledge, skills, and attitudes has been required as a differential for the provision of comprehensive, interprofessional, safe, and quality care, characterizing the crucial need for high performance in the context of training, and also in the work environment. ${ }^{1}$

In many settings, healthcare professional training has faced the scarcity of well-organized clinical experience opportunities, which may contribute to the occurrence of flaws in the profile of a competent individual with characteristics that are essential to health care performance.

In nursing, as in other healthcare professions, the clinical practice that takes place in laboratories, or in healthcare settings, is a significant part of the learner training. However, the opportunities found in these environments do not always meet the demands or requirements of students, either due to a lack of physical, human, material, and financial resources, or even given the profile of care provided in the unit, which directly interferes with the training process. Training may have limitations that impair the effectiveness of the practice-based learning process. ${ }^{2}$

Therefore, it is essential to develop teaching strategies that focus on better qualification and training of future professionals, aiming at safety and quality of the care provided to patients. In nursing, the positive impact of active methodologies on student training is evident, especially those benefiting from the simulated method in teaching and learning processes. ${ }^{3,4}$

Clinical simulation is a promising teaching method because it allows students to relate theory and practice; it repeats essential aspects of a clinical situation in a controlled environment, allowing for errors without causing actual harm to patients or students, that is, it allows both to remain ethically protected. This way, students are fully prepared in advance, in the simulated context, becoming competent to deal with the situation and solve problems when it is similar to a real context. ${ }^{4}$

In clinical simulation, it is possible to use the resources that provide not only skills training but also more advanced care, which include the use of clinical reasoning and decision making in solving scenarios.

The planning of well-designed simulated scenarios with welldefined learning objectives that are built to general and specific skills obtainment allows students to anticipate the experience of situations that are similar to the nurses' daily reality. The closest to real situations and the greater the use of the necessary skills to solve the scenario, the greater the level of its complexity; they can be named as scenarios of low, medium and high complexity. ${ }^{5}$

In order for the simulation to be effective, it is necessary that the resources used be in accordance with the established learning objectives, which will determine the selection between the use of artificial simulators or of a scenic or hybrid simulation (when the use of these types of simulation is mixed).
The artificial simulators used are characterized as low-, medium-, or high-fidelity simulators. Depending on the communication, information or robotic technologies that they incorporate, they can provide more real scenarios. ${ }^{6}$

Scenic simulation includes techniques using actors or other students and professionals, which characterize what we call simulated patients (students or professionals of performing arts, or from other courses, who play the role of patients), role-playing (when a professional or student assumes the role of a certain, and different, professional), standardized patients (patients contracted to act as patients), and mixed models (by the union of a simulated patient and a simulator where it is usually possible to develop a procedure). ${ }^{7}$

When the scenario uses scenic simulation features, some items such as clothing and personal utensils of a real patient (hygiene and personal care materials, books, religious articles, and so on) can make the environment more real. Among the resources used to help with this, we can also highlight the use of artistic makeup, body painting or even graphic printing of lesions on transparent adhesive labels, which can reproduce lesions, trauma, bruises, burns, among others, ensuring the veracity of the clinical scenario and of the simulation. ${ }^{8}$ These resources allow us to portray factors present in nurses' daily routine and care, such as the occurrence of pressure injuries (PI).

Pressure injuries consist of localized damage to the skin and/or underlying soft tissues. They usually occur on a bone prominence, or are related to the use of a medical device or another artifact. They can develop as an intact skin lesion or an open ulcer, followed or not by pain. The lesion results from intense and/or prolonged pressure, in combination with local shearing. Tolerance of soft tissue to pressure and shear can also be affected by microclimate, nutrition, perfusion, comorbidities, and its condition. ${ }^{9}$

Pressure injuries are characterized by a negative indicator of care quality. They are internationally evaluated as an adverse event, and represent an important challenge for health care because they can increase morbidity, mortality, and treatment length and costs, affecting a large number of people. In Brazil, the Ministry of Health, through Ordinance No. 529, of April 1, 2013, instituted the National Patient Safety Program, in which one of the objectives is to reduce the occurrence of PI. ${ }^{10,11}$

The US National Pressure Ulcer Advisory Panel (NPUAP), the European Pressure Ulcer Advisory Panel (EPUAP), and the Pan Pacific Pressure Injury Alliance (PPPIA) have recently published new international guidelines for the prevention and treatment of pressure injuries, establishing recommendations for the development of public policies, education, and research on the treatment and prevention of pressure injuries. ${ }^{12}$

The occurrence of $\mathrm{PI}$ is considered an adverse event that can, most of the time, be avoided. However, in some occasions the patient's physiological conditions make the lesions unavoidable, even using preventive measures. ${ }^{13}$ 
People with decreased sensitivity, prolonged immobility, or bedridden individuals with old age are more likely to have $\mathrm{Pl}$, which most frequently takes place in the mental, occipital, scapular, ankle, sacral, ischial, trochanter, iliac crest, knee, malleolus, and calcaneum regions. Other factors that increase the risk of developing $\mathrm{Pl}$ include degenerative diseases, reduced tissue tolerance (fragile skin), urinary or intestinal incontinence, and malnutrition or obesity. In these cases, the implementation of appropriate care is crucial, which instigates the nurse to seek training for the recognition of the problem and for new interventions. ${ }^{13}$

Theoretical training on care for people with $\mathrm{PI}$ is usually complemented by clinical practice in which students can observe, stage and treat wounds in a real practical context. However, the demands of working environments are often not met and understood by the professionals being trained. Studies indicate that high rates of $\mathrm{PI}$, especially in at-risk populations, represent a challenge for health professionals in the implementation of preventive actions and use of treatment technological advances. 10,14,15

Among the resources for the treatment, the use of dressings with different types of covering is considered the conventional therapy. They benefit the healing process in the mid- and long term, depending on the staging, based on the degree of lesion tissue destruction, and the patient's conditions. ${ }^{13}$

In nursing, the practice based on scientific evidence begins during formal education and is an essential factor for the feasibility and implementation of care for PI prevention and treatment. During graduation, the nursing student should obtain sufficient skills to care for individuals at risk of developing PI or who have wounds during the practice of care.

In this context, as a goal for the development of this teachinglearning object, clinical simulation can be a valuable resource. Simulated scenarios that involve $\mathrm{PI}$ can be developed in a context that incorporates clinical elements that are essential to wound treatment and/or prevention of the occurrence, not only focused on the development of technical skills to perform dressings and the use of coverages, but also on patient care. This study aims to describe the construction of a high-fidelity simulated clinical scenario intended for the teaching-learning of nursing care for PI patients.

\section{METHOD}

This is an experience report that describes the construction of the simulated clinical scenario "Nursing Care to Patients with Pressure Injury", offered to undergraduate nursing students as part of a workshop called "Hospitalized Clinical Patient Nursing Care". The team of researchers involved comprised undergraduate and graduate students in nursing and in information and communication technologies, and nursing and medical professors. All the staff has experience and training in simulated practices and/or PI treatment.
The event was offered to nursing undergraduate students at the simulation center of a Brazilian public university located in a city in the state of São Paulo. The event was held in two days to different publics, previously enrolled, and lasted 4 hours/day/ class. During the event, undergraduates participated in 4 different scenarios in groups of 12 to 15 members. The activities were scheduled and released in August and September 2016 and developed in October 2016.

The scenario planning was based on Bloom's taxonomy. ${ }^{16}$ Built in the 40's and revised forty years later, this taxonomy received the collaboration of several researchers who proposed three domains: cognitive, affective and psychomotor. The cognitive domain is the most studied, and considers knowledge as something acquired, constructed or used to solve daily and eventual problems. It involves the apprehension of new knowledge, and is related to learning. In this domain the objectives were grouped into categories that have a hierarchical level, but that in certain situations can assume greater flexibility and interpolation. The categories of this domain are: 1) remember, 2) understand, 3) apply, 4) analyze, 5) synthesize, and 6) create. The affective domain is related to the feelings and attitudes that involve the emotional and the affective areas. Its categories are: receptivity, response, valuation, organization, and characterization. In this domain, in order to upgrade to a new category it is necessary to acquire the previous capabilities. The psychomotor domain includes physical abilities. The categories of this domain involve imitation, manipulation, articulation, and naturalization. ${ }^{17}$

To guide the development of the scenario, we also used the items defined by other authors. ${ }^{18}$ This study was approved by the Research Ethics Committee of the Ribeirão Preto College of Nursing at University of São Paulo (322/2016). Informed consent forms and image use consent forms were obtained.

\section{RESULTS}

\section{Event dissemination and invitation}

The event was publicized through social networks and the electronic address of the educational institution. One hundred seats were offered per event day, and 100 enrolments were received. All the enrollees had their registration confirmed and received previous messages to encourage participation confirming the day of the event. Among the 100 enrollees, 55 undergraduates participated in the event on the first day, and 45 undergraduates on the second day.

At the event, the participants were offered four simulated clinical scenarios of nursing care considering: 1) a patient with abdominal ascites, 2) a colostomy patient, 3) an adult patient in diapers, and 4) a patient with pressure injury, with the latter being the focus of this study. The participants had 5 minutes during the scenario for recognition of the environment, 15 minutes for the development of the scenario and 30 minutes for the respective debriefings. 


\section{The learning objectives of the simulated clinical scenario "Nursing Care to Patients with Pressure Injury"}

The general learning objective defined for the scenario was: at the end of the scenario activities students should be able to provide nursing care to patients with $\mathrm{PI}$.

Specific objectives were also defined, namely: students should be able to identify the need for a dressing and change of coverage in the PI, evaluate and classify the PI found; guide the patient about the dressing and other procedures that imply in the improvement of the general condition of the Pl; select the material and the suitable cover(s) to make the dressing; perform the intervention (replace PI dressing), and reassess the patient's conditions.

\section{Previous study material}

To allow the event participants to access the theoretical content, the researchers in charge carried out a bibliographical survey of the current published guidelines and studies on the prevention and treatment of $\mathrm{PI}$. The selected material was sent by e-mail in advance to all participants in the workshop with guidance on the study of texts. Before the beginning of the scenario, the researchers/facilitators demonstrated the coverages available for use in the simulated clinical case, explaining the action and the indication of each coverage, associating them with the staging of the PI.

\section{Scenario fidelity}

The scenario developed had high fidelity or complexity. It lasted about 15 minutes. The scenario involved complex thinking, clinical reasoning, decision making, and intervention. After the clinical evaluation of the patient and $\mathrm{PI}$, students had to guide the patient, choose the best coverage to be used, perform the dressing and make the necessary guidelines on patient and team follow-up. The whole scenario was developed in a nursing team, in a group of three students.

\section{Clinical case/situation}

Pre-briefing or briefing was presented to the students in the form of a clinical case through the shift reporting by the nurses of the morning shift to those of the afternoon shift, and it was made available in written form in the patient's medical record. The clinical case was: A.C.G, a female patient, 34 years old, Caucasian, married, two children, secretary, an inhabitant of the city of São Simão/SP, who studied until the $8^{\text {th }}$ year of elementary school, family income of three minimum wages. On 09/18/2016 she was admitted to the Municipal Hospital Santo Antônio in the city of São Simão, with a diagnosis of acute digestive hemorrhage $(A D H)$, due to gastric ulcer without a previous diagnosis. She presented a lower level of consciousness, hemodynamic instability, requiring ventilation support, vasoactive drugs, and a bed in the intensive care unit. On 09/26/2016 she was transferred and admitted to the ward of the $5^{\text {th }}$ floor. At the moment, the patient was conscious, oriented, calm, communicative, showing spontaneous breathing with oxygen support $\left(\mathrm{O}_{2}\right)$ in oxygen nasal catheter glasses at $21 / \mathrm{min}, \mathrm{O}_{2}$ saturation $94 \%$, blood pressure $130 \times 80 \mathrm{mmHg}$, heart rate 96 beats/min, axillary temperature of $37.6^{\circ} \mathrm{C}$. she had peripheral venous access in the upper right limb in the antecubital region with a teflon-type flexible catheter No. 20, salinized. She received oral diet with low acceptance. She had an occlusive dressing, with a large exudate $(+++/ 4+)$ of yellowish color and fetid odor, on the left trochanter region. The need for injury assessment was informed.

\section{Material and human resources used in the scenario}

Scenic simulation was used to develop the simulated scenario. The activity took place in the form of role-playing, where an undergraduate student played the role of the patient. Before the activity, through a previously formulated script, the student was guided by the researchers. Guidelines were given for speech, intensity of referred pain, body posture, answers to be provided in the clinical case, among others.

The undergraduate student who played the role of the patient wore a hospital gown and adult disposable diaper. The makeup made the facial skin color pale. In the left trochanter of the undergraduate student, a PI of stage 3 was constructed, that is, when there is loss of the skin in its total thickness, the depth of the tissue damage varies according to the anatomical location, and detachment and tunnels may occur. There is no exposure of fascia, muscle, tendon, ligament, cartilage and/or bone; infected, with presence of exudate and odor. ${ }^{9}$

The lesion was constructed using moulage techniques, using materials such as makeup to simulate clinical aspects, and its fidelity can be evaluated by the validity of realism and content. To make the moulage, the wound was characterized by a magical mass (slug ${ }^{\circledR}$ ); latex, powder facial foundation, red and yellow ink, commercial blood, wine color stain, glucose and gorgonzola cheese. Mashed banana was also used to characterize the exudate.

The simulated scenario was developed in the simulation center of the teaching unit, which has the necessary fixed infrastructure that imitates the hospital environment, with an electronic bed with head, gas netting, bedside table, ladder, hospital garments, screens, saline solution holder, hamper for dirty clothes, nursing workstation with sinks and hand basin, among others. All supplies needed for patient care were available, such as an oxygen therapy device (oxygen glasses catheter), macrodrop intravenous infusion device, flexible needle device, saline solution $0.9 \%$, and peripheral oximetry. All materials (instruments, coverages, saline $0.9 \%$, gauze) needed to perform the dressing were available at the nursing station, and the coverages were provided by a private company. 


\section{Problem solving}

After the presentation of the clinical situation, the participants started patient care. The degree of veracity of the scenario was carefully calculated to reflect the previous study material and the technical exposure of the use of coverages in student injuries. For the problems proposed in the activity to be solved, the preparation of apprentices was taken into account. We also used clues (student talk/simulated patient) to lead students to successful learning. ${ }^{19}$

\section{Scenario face and content validity}

For the validation process, experts were invited after the construction of the scenario to analyze and judge the items related to the proposed scenario and with experience in the areas and topics of interest: clinical simulation and nursing care to patients with pressure injury. For the participation of the experts, an invitation to participate in the study in electronic form, informed consent form, instrument of characterization of the subjects, instrument of analysis of content and scenario to be validated were sent. A deadline of 30 days was defined for returning the documents. Among the 5 experts invited, the level of agreement considered was $80.0 \%$ among the judges for each item of the scenario to be validated. ${ }^{20}$ They suggested the inclusion of some references, book chapters, skills training, preparation of reading material, and follow-up checklist to participants.

\section{Debriefing}

Soon after the end of the scenario, the facilitators invited the three participating students, together with the other students who were in the room and who watched the simulated clinical scenario, to carry out the structured debriefing. Participants were asked to describe the activity and to report positive aspects and the aspects to be improved. ${ }^{21}$ Positive teamwork, communication, leadership, patient safety and comfort, empathy and experienced feelings were scored as positive, which were strengthened and discussed in depth. The knowledge about the coverages, with emphasis on their clinical application, the classification and types of tissues present in the $\mathrm{PI}$, communication with the patient, decision making and resolubility, the need for greater effectiveness of professionals, among others, were items chosen to be better developed.

\section{Evaluation}

After the debriefing, the students evaluated the activity in a dialogue and using the instruments: 1) Satisfaction Scale with Simulated Clinical Experiences (ESECS) ${ }^{22}$ and the Satisfaction and Self-Confidence Learning Scale (Student Satisfaction and Self-Confidence in Learning) of the National League for Nursing (NLN). ${ }^{5,23}$ Both are Likert-type instruments that evaluate students' satisfaction with simulated clinical activities, and the second also evaluates students' self-confidence. High scores (> 89\%) of satisfaction and self-confidence were found.

\section{DISCUSSION}

Clinical simulation scenarios provide participants with experiences that run through practical experiences. They reach cognitive, psychomotor and affective factors, contributing to the transfer of knowledge from the classroom to clinical settings. ${ }^{24,25}$

In the health area, students seek experiences close to the actual clinical practices through simulation, so they can develop competencies related to the identification of patients' health needs through the collection of clinical history, physical examination, development of necessary interventions, resources management, and available health staff. ${ }^{26}$

The literature has shown that students who have previous contact with the simulated practice develop self-confidence and feel better prepared for clinical practice. In this sense, the role of the facilitator should be judicious as to the originality, reality, complexity and resources available for the development of the simulation. ${ }^{18}$

During the development of a simulated activity, the teachinglearning objectives should be defined according to the desired results. Using Bloom's taxonomy, and its hierarchical classification of learning objectives, the educators consciously seek ways of stimulating their students' reasoning and high-level abstractions, without distancing them from the previously proposed instructional objectives. ${ }^{16}$ An instructional goal is a clear description of the performance and competence that educators would like that their learners demonstrated before being considered knowledgeable about certain subjects. This objective is linked to an intentional result directly related to the content and to the way it should be applied ${ }^{27}$ The authors recommend three or four objectives for each scenario, and that the scenario lasts up to 10 minutes. ${ }^{19}$

Regarding student involvement, clinical simulation should include prior preparation, action, and reflection of the activity. The previous preparation of the scenario is associated with the theoretical and procedural content, and the manipulation of the scenario resources (Figure 1); the action is related to the development of the scenario (Figure 3), and the reflection covers the moment of debriefing, in which the professor/facilitator directs the discussion in order to encourage students. ${ }^{19}$

The prior knowledge of students comprises the organization to incorporate, understand and memorize new information. With this, the professor/facilitator, with the use of teaching strategies and didactic situations, is successful because the student assimilates the new learning by mobilizing the previous content. In this sense, the reference material should offer a structured and logical content. Thus, the professor/facilitator defines the competencies to be achieved, the complexity of the activity, and the objectives of the simulated scenario. ${ }^{18}$

The fidelity or complexity of the scenario is not associated with the high complexity of the resources used, but it is associated with fidelity of reproduction of the clinical reality, the complexity of situations involved, teamwork, among others. ${ }^{6}$ Well-designed scenarios bring students closer to clinical practice and bring 
Figure 1. Simulated scenario of nursing care to the patient with a pressure injury - Ribeirão Preto - 2016. Image source: Author's personal file.

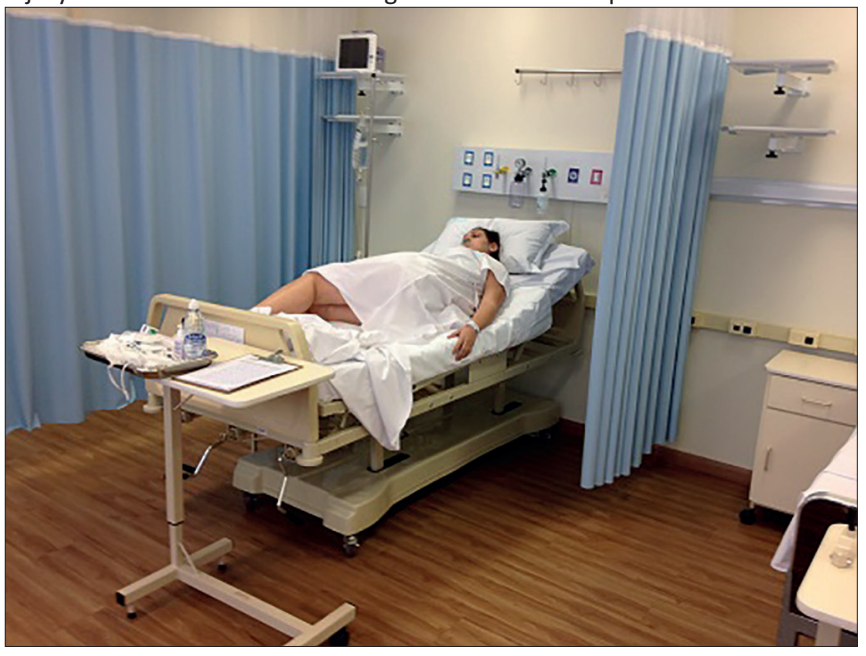

Figure 2. Moulage technique used to produce pressure injury (stage 3), with irregular border, necrotic tissue, granulation tissue, and slough - Ribeirão Preto - 2016. Image source: Author's personal file.

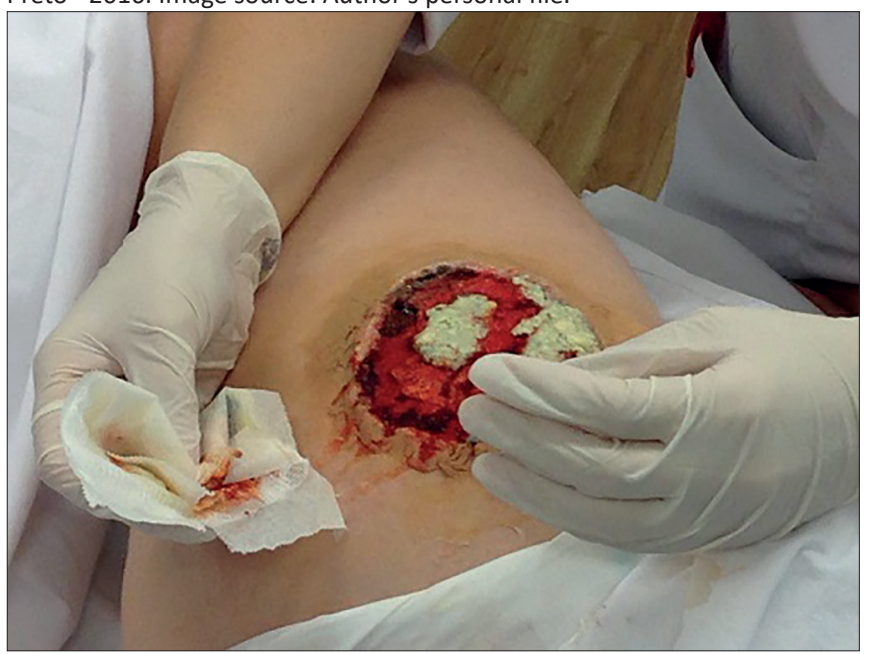

positive experiences that guide their acquisition of knowledge. The simulated practice overcomes the feeling experienced in traditional teaching, helps to confront clinical practice and minimizes feelings of fear and anxiety about the profession. ${ }^{28}$

In the pre-briefing or briefing, the information conveyed to learners during the simulated clinical scenario should be clear and concise. There should be no information that is irrelevant to the development of the activity so it does not lead to confusion, the clinical case can be presented in writing or be projected in media to the students. To complement this step, one can also use resources such as the patient's medical record, test results, other records, and information transmitted by other professionals (other participants in the scenario).

Regarding the human resources used in this study, some studies have shown that gains related to empathy and knowledge in communication skills are more effective in students who play roles in scenarios with the use of role players or simulated patients. ${ }^{6}$ In this scenario, the moulage technique (Figure 2) was used to construct the wound in the undergraduate student. One study demonstrated that moulage in wound construction contributes positively to simulation experience. ${ }^{29}$

Debriefing is a crucial stage of the simulation, in which the facilitator provides a discussion session for the participants to retake the positive facts and the facts to be better developed, establishing a relation between theory and practice. It is a stage of reflection on the simulated clinical experience, which causes the development of clinical judgment. ${ }^{28,30,31}$ In the debriefing, the simulation participants are invited to present a report of what happened, what was performed and how the activity was performed to solve the situation proposed in the clinical scenario. ${ }^{30}$

It should be explicit to the participants that the debriefing is not related to the evaluation and/or ridicule of the students; it aims to identify different perceptions and attitudes by the learner; to relate the exercise and the theory or content, and the technical skills; to allow the transmission of feedback about nature and

Figure 3. Development of the scenario - Ribeirão Preto - 2016. Source: Author's personal file.

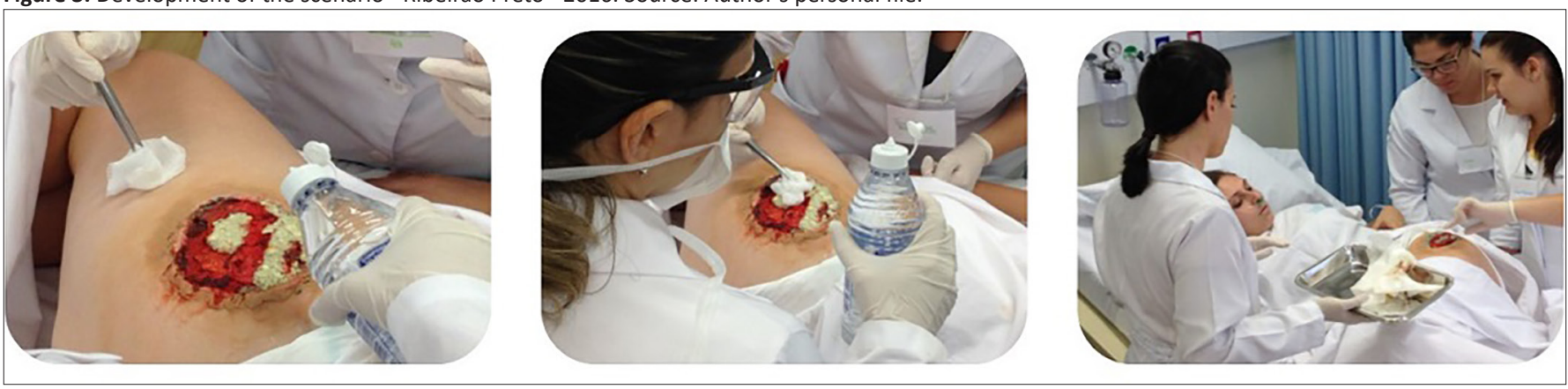


practice during the scenario in a comfortable atmosphere for the participants. When debriefing is used in a structured way, it is associated with learners' gains. ${ }^{22,30,31}$

It is intended to occur in a respectful learning environment, which provides participants' feedback, expression of their emotions, preserving students' confidence and self-esteem. It is the phase of the method that takes the greatest time, and due to its relevance, it should be structured, planned and directed to the promotion of critical and reflective thinking by the participants. ${ }^{31}$

This is a study carried out in Brazil that analyzed the perception of nursing students about the simulation strategy in the development of competency of risk assessment for pressure ulcer, resulting in satisfaction and enthusiasm with the strategy, knowledge, skills and attitudes, providing a theoretical critical reflection. ${ }^{32}$

Simulation as a pedagogical strategy allowed the interaction of students in their teaching-learning process; the improvement of their skills, problem solving, and experiences in complex clinical behaviors. The training of competent professionals has been a requirement of the labor market. In this context, the use of well-designed simulated scenarios requires careful planning, and has a cost that involves the training of professors and actors to ensure that the scenarios are faithful to provide students with experience-based learning; which leads students to learn in a critical and reflexive way through their experiences, providing an active formation in all its process, assisting in the construction of the required competencies.

\section{CONCLUSION}

The planned and structured simulated clinical scenarios that use scenic simulation through role-playing can be an excellent helper for clinical activities where clinical reasoning, decision making, and interaction with patients are needed. There are many features that can make simulated activity more truthful, such as the use of foods that give PI the characteristics of large amount of exudate and/or the odor of an infected lesion. These resources help the teaching-learning process, and in professionals updating on injury prevention and treatment, which contributes positively to the development of the learner and to the safety and quality of patient care.

\section{REFERENCES}

1. Furukawa PO, Cunha ICKO. [From management competencies to nurse managerial competencies]. Rev Bras Enferm [Internet]. 2010 Nov/Dec [cited 2017 Nov 8]; 63(6):1061-6. Available from: http://www.scielo.br/ $\mathrm{pdf} / \mathrm{reben} / \mathrm{v63n6/30.pdf.} \mathrm{Portuguese.}$

2. Morente L, Morales-Asencio J, Veredas FJ. Effectiveness of an e-learning tool for education on pressure ulcer evaluation. J Clin Nurs [Internet] 2013; [cited 2017 Nov 8]; 23(13-14):2043-52. Available from: http:// onlinelibrary.wiley.com/doi/10.1111/jocn.12450/epdf
3. Baptista RCN, Martins JCA, Pereira MFCR, Mazzo A. Simulação de Alta-Fidelidade no Curso de Enfermagem: ganhos percebidos pelos estudantes. Rev Enferm Ref [Internet].2014 Feb/Mar; [cited 2017 Nov 8] 4(1):135-44. Available from: http://www.scielo.mec.pt/pdf/ref/vserlVn1/ serlVn1a15.pdf

4. Almeida RGS, Mazzo A, Martins JCA, Negri EC, Della Torre BFM, Ventura CAA, et al. Meanings attributed by nurses to ensure the care of critical patients in the light of simulations' premises. Appl Nurs Res [Internet]. 2016 Aug; [cited 2017 Nov 8]; 31:170-4. Available from: http://ac.els-cdn. com/S0897189716000264/1-s2.0-S0897189716000264-main.pdf? tid=e8f175be-e6ef-11e6-b586-00000aacb362\&acdnat $=1485783056$ ce9e455b7d33dee24a13ddf027b5a8d0

5. Almeida RGS, Mazzo A, Martins JCA, Baptista RCN, Girão FB, Mendes IAC. Validation to Portuguese of the Scale of Student Satisfaction and Self-Confidence in Learning. Rev Latino Am Enferm [Internet]. 2015 Nov/Dec; [cited 2017 Nov 8];23(6):1007-13. Available from: http://www. scielo.br/pdf/rlae/v23n6/0104-1169-rlae-23-06-01007.pdf

6. Martins JCA, Mazzo A, Baptista RCN, Coutinho VRD, Godoy S, Mendes IAC, et al. The simulated clinical experience in nursing education: a historical review. Acta Paul Enferm [Internet]. 2012; [cited 2017 Nov 8] 25(4):619-25. Available from: http://www.scielo.br/pdf/ape/v25n4/22.pdf

7. Oliveira SN, Prado ML, Kempfer SS. Utilização da simulação no ensino da enfermagem: revisão integrativa. Rev Min Enferm [Internet]. 2014 Apr/Jun; [cited 2017 Nov 8]; 18(2):487-504. Available from: http://www. reme.org.br/artigo/detalhes/941

8. Smith-Stoner M. Using moulage to enhance educational instruction Nurse Educ [Internet]. 2011 Jan/Feb; [cited 2017 Nov 8]; 36(1):21 4. Available from: http://journals.Iww.com/nurseeducatoronline/ Abstract/2011/01000/Using_Moulage_to_Enhance_Educational_ Instruction.10.aspx

9. Caliri MHL, Santos VLCG, Mandelbaum MHS, Costa IG. Classificação das lesões por pressão - consenso NPUAP 2016: adaptada culturalmente para o Brasil. Associação Brasileira de Estomaterapia (SOBEST). Associação Brasileira de Enfermagem em Dermatologia (SOBENDE). São Paulo; 2016. [cited 2017 Nov 8]. Available from: http:// www.sobest.org.br/textod/35

10. Bernardes RM, Caliri MHL. Pressure ulcer prevalence in emergency hospitals: a cross-sectional study. Online Braz J Nurs [Internet]. 2016 Jun; [cited 2017 Nov 8]; 15(2):236-44. Available from: http://www. objnursing.uff.br/index.php/nursing/article/view/5391/pdf_1

11. Ministério da Saúde (BR). Portaria № 529, de 1ํ de abril de 2013 . Institui o Programa Nacional de Segurança do Paciente (PNSP) [Internet]. Brasília (DF): Ministério da Saúde; 2013. [cited 2016 Mar 29]. Available from: http://bvsms.saude.gov.br/bvs/saudelegis/gm/2013/ prt0529_01_04_2013.html

12. National Pressure Ulcer Advisory Panel, European Pressure Ulcer Advisory Panel, Pan Pacific Pressure Injury Aliance. Prevention and Treatment of Pressure Ulcers: Clinical Practice Guideline. Washington: NPUAP/EPAUAP/PPPIA; 2014.

13. Palagi S, Severo IM, Menegon DB, Lucena AF. Laser therapy in pressure ulcers: evaluation by the Pressure Ulcer Scale for Healing and Nursing Outcomes Classification. Rev Esc Enferm USP [Internet]. 2015; [cited 2017 Nov 8]; 49(5):820-6. Available from: http://www.scielo.br/pdf/ reeusp/v49n5/0080-6234-reeusp-49-05-0826.pdf

14. Martin D, Albensi L, Van Haute S, Froese M, Montgomery M, Lam M, et al. Healthy Skin Wins: a glowing pressure ulcer prevention program that can guide evidence-based practice. Worldviews Evid Based Nurs [Internet] 2017; [cited 2017 Nov 8]; 1-11. Available from: http://onlinelibrary.wiley. com/doi/10.1111/wvn.12242/epdf

15. Rogenski NMB, Kurcgant P. The incidence of pressure ulcers after the implementation of a prevention protocol. Rev Latino Am Enferm [Internet]. 2016 Mar/Apr; [cited 2017 Nov 8]; 20(2):333-9. Available from: http://www.scielo.br/scielo.php?script=sci_arttext\&pid =S0104-11692012000200016 
16. Conklin J. A taxonomy for learning, teaching and assessing: a revision of Blooms's taxonomy of education objectives. Educ Horiz [Internet]. 2005; [cited 2017 Nov 8]; 83(3):154-9. Available from: http://www.jstor. org/stable/pdf/42926529.pdf

17. Ferraz APCM, Belhot RV. Taxonomia de Bloom: revisão teórica e apresentação das adequações do instrumento para definição de objetivos instrucionais. Gest Prod [Internet]. 2010; [cited 2017 Nov 8]; 17(2):421-31. Available from: http://www.scielo.br/scielo. php?script=sci_arttext\&pid=S0104-530X2010000200015

18. Fabri RP, Mazzo A, Martins JCA, Fonseca AS, Pedersoli CE, Miranda FBG, et al. Construção de um roteiro teórico-prático para simulação clínica. Rev Esc Enferm USP [Internet]. 2017; [cited 2017 Nov 8]; 51:e03218. Available from: http://www.scielo.br/pdf/reeusp/v51/ pt_1980-220X-reeusp-51-e03218.pdf. DOI: http://dx.doi.org/10.1590/ S1980-220X2016016403218

19. Jeffries PR, McNelis AM, Wheeler CA. Simulation as a vehicle for enhancing collaborative practice models. Crit Care Nurs Clin North Am [Internet]. 2008 Dec; [cited 2017 Nov 8]; 20(4):471-80. Available from: http://ac.els-cdn.com/S0899588508000580/1s2.0-S0899588508000580-main.pdf?_tid=25830682-e713-11e6877 b-00000aab0f26\&acdnat $=1485798190 \_$eb3cdb6f7a6adbcf098fa2b9c3a5dd07

20. Grant JS, Davis LL. Selection and use of content experts for instrument development. Res Nurs Health [Internet]. 1997 Jun; [cited 2017 Nov 8]; 20(3):269-74. Available from: http://onlinelibrary.wiley.com/doi/10.1002/ (SICl)1098-240X(199706)20:3\%3C269::AID-NUR9\%3E3.0.CO;2-G/ epdf

21. Shinnick MA, Woo M, Horwich TB, Steadman R. Debriefing: The most important component in simulation? Clin Simul Nurs [Internet]. 2011 May; [cited 2017 Nov 8]; 7(3):105-11. Available from: http:// www.nursingsimulation.org/article/S1876-1399(10)00198-2/pdf. DOI: 10.1016/j.ccns.2010.11.005

22. Baptista RCN, Martins JCA, Pereira MFCR, Mazzo A. Student satisfaction with simulated clinical experiences: validation of assessment scale. Rev Latino Am Enferm [Internet]. 2014 Sep/Oct; [cited 2017 Nov 8]; 22(5):709-15. Available from: http://www.scielo.br/ pdf/rlae/v22n5/pt_0104-1169-rlae-22-05-00709.pdf

23. Hastead JA, BonnelW, Chamberlain B, Green PM, Hanna KR, Heinrich $\mathrm{C}$, et al. Core competencies of nurse educators with task statements. NLN [Internet]. 2005; [cited 2017 Nov 8]; 8. Available from: http://www. wgec.org/resources/art/nursing-core-competencies.pdf
24. Gomez MV, Vieira JE, Scalabrini Neto A. Análise do perfil de professores da área da saúde que usam a simulação como estratégia didática. Rev Bras Educ Med [Internet]. 2011 Apr/Jun; [cited 2017 Nov 8]; 35(2):15762. Available from: http://www.scielo.br/scielo.php?script=sci_arttext\& pid=S0100-55022011000200003

25. Reid-Searl K, Eaton A, Vieth L, Happell B. The educator inside the patient: students' insights into the use of high fidelity silicone patient simulation. J Clin Nurs [Internet]. 2011 Oct; [cited 2017 Nov 8]; 20(19-20):2752-60. Available from: https://www.ncbi.nlm.nih.gov/ pubmed/21831109

26. Solum EM, Maluwa VM, Tveit B, Severinsson E. Enhancing students' moral competence in practice: Challenges experienced by Malawian nurse teachers. Nurs Ethics [Internet]. 2016 Sep; [cited 2017 Nov 8]; 23(6):685-97. Available from: https://www.ncbi.nlm.nih.gov/ pubmed/25991658

27. Mager RF. Preparing instructional objectivesBelmont: Lake Publishers Co; $1984.136 \mathrm{p}$.

28. Liaw SY, Koh Y, Dawood R, Kowitlawakul Y, Zhou W, Lau ST. Easing student transition to graduate nurse: a simulated professional learning environment (SIMPLE) for final year student nurses. Nurse Educ Today [Internet]. 2014 Mar; [cited 2017 Nov 8]; 34(3):349-55. Available from: https://www.ncbi.nlm.nih.gov/pubmed/23706963. DOI: 10.1016/j. nedt.2013.04.026

29. Pywell MJ, Evgeniou E, Highway K, Pitt E, Estela CM. High fidelity, low cost moulage as a valid simulation tool to improve burns education. Burns [Internet]. 2016 Jun; [cited 2017 Nov 8]; 42(4):84452. Available from: http://www.sciencedirect.com/science/article/pii/ S0305417916000036

30. Almeida RGS, Mazzo A, Martins JCA, Coutinho VRD, Jorge BM, Mendes IAC. Validation to Portuguese of the Debriefing Experience Scale. Rev Bras Enferm [Internet]. 2016 Jul/Aug; [cited 2017 Nov 8]; 69(4):705-11. Available from: http://dx.doi.org/10.1590/00347167.2016690413i

31. Coutinho VRD, Martins JCA, Pereira M. Structured debriefing in nursing simulation: students' Perceptions. J Nurse Educ Pract [Internet]. 2016; [cited 2017 Nov 8]; 6(9):127-34. Available from: http://www.sciedu.ca/ journal/index.php/jnep/article/view/8878/5824

32. Moura ECC, Caliri MHL. Simulação para desenvolvimento da competência clínica de avaliação de risco para úlcera por pressão. Acta Paul Enferm [Internet]. 2013; [cited 2017 Nov 8]; 26(4):369-75. Available from: http://www.scielo.br/scielo.php?script=sci_arttext\&pi $d=S 0103-21002013000400011$ 